Journal of Science Education Research

Journal homepage: www.journal.uny.ac.id/jser

JSER

\title{
Development of Project-Based Learning Science Module to Improve Critical Thinking Skills of Junior High School Students
}

\author{
Widodo Setiyo Wibowo $^{1 *}$, Ekosari Roektiningroem ${ }^{2}$, Norma Bastian ${ }^{3}$, Karina Syahrul Hudda $^{4}$ \\ 1,2,3,4 Department of Science Education, Faculty of Mathematics and Natural Sciences, Universitas Negeri Yogyakarta. \\ 3, Department of Science Education, Faculty of Teacher Training and Education, Universitas Muhammadiyah Cirebon. \\ Corresponding Author. Email: widodo setiyo@uny.ac.id
}

\section{Keywords: \\ Project Based \\ Learning, Critical \\ thinking skills, \\ Module}

\begin{abstract}
The study was conducted to develop science module based on project-based learning that is feasible to be implemented in science learning and has potency to build critical thinking skills of junior high school students. The study was Research and Development (R\&D), modified from Borg \& Gall steps covering only research and information collecting, planning, preliminary form of product development, expert judgment, product revision, and final product. The subjects were 2 expert lecturers (content expert and media expert) and 2 science teachers of SMP N 1 Wonosari. The types of data were quantitative and qualitative. Data were collected by means of SSP validation sheets and disaster preparedness identification sheets. The techniques of data analysis were descriptive analysis of qualitative and quantitative to 5 grading scale. The result of the study shows that science module is feasible to be implemented in science learning and has potency to build critical thinking skills of junior high school students.
\end{abstract}

\section{INTRODUCTION}

Introduction In 21 st century era, various fields of life experiences a paradigm shift. A good illustration is shown in the workplace, in which the types of currently jobs demand skills that are different from the previous period. According to the National Education Association (NEA) (2002), jobs that require routine skills have experienced a temporary decline. However, jobs that require non-routine, analytical, and interactive communication skills continue to increase. Consequently, educational system needs to be improved to face this challenge. It should be able to facilitate students to acquire 21 st century skill because Rotherdam \& Willingham (2009) note that a student's success depends on their 21 st century skills. There are 18 types of 21 st century skills that need to be mastered by students (NEA, 2002). Nevertheless, learning and innovation skills4Cs, namely critical thinking, communication, collaboration, and creativity, is the most important skill for students in elementary to secondary education.

Among the 4Cs skill, critical thinking skill is one of the most essential, because it has been singled out as one of the most important skills for citizens of the 21st century (Halpern, 2014). Critical thinking is an attempt to deepen the consciousness and intelligence of comparing some of its problems to produce a conclusion and ideas that can solve the problem (Zulfaneti et al, 2018, p.1). By mastering it, students are able to build arguments using reliable evidence and logical reasoning. Furthermore, they can distinguish between truth and untruth, appearance and reality, facts and opinions, knowledge and beliefs. That is why they can formulate or solve problems and make decisions.

Critical thinking skills can be mastered by students if teacher integrate it into learning process (Wibowo, 2014, p.276). Partnership for 21 st Century Skills (2009) states that it can be 
integrated through various subjects, one of them is science. Essentially, science is a way of thinking, including beliefs, curiosity, imagination, thought, cause-effect relationship, self-examination, scepticism, objectivity, and open-mindedness (Chiappeta and Kobala, 2010, p.105). Thus, science learning is a potential media to develop critical thinking skills. Through appropriate approaches, science learning is expected to encourage students to be literate in science and technology, able to think logically and critically, argue rationally, and act comprehensively in solving various problems in real life.

Unfortunately, some of science teaching practices have not run optimally in term of facilitating students' critical thinking skills. In general, science teaching practices still tend to use lecturing and drilling questions to complete target subject matter and national exam scores. Students only memorize knowledge but are not trained to carry out scientific processes. The lecture format of learning frequently does not encourage active learning or critical thinking on the part of students (Duron et al, 2006, p.160). Hence, it is not surprising that students' critical thinking skills are still low. This is reflected in the results of the 2015 Program for International Student Assessment (PISA), in which Indonesian student science score are still below the average of OECD countries (Kemdikbud, 2016). These results suggest that students are only able to answer test questions that measure recalling, understanding, and few applications, and have not been able to answer analytical questions and problem solving that are strongly related to critical thinking skills.

Based on these data, improvements of science teaching are necessary. Learning objectives should be directed at the development of critical thinking skills. It is the priority in the goals of education (Budi Utami et al, 2017, p.124). To realize this objective, of course, appropriate learning activities and learning tools are needed. Learning models that support in integrating critical thinking skills are project-based learning (PBL) (NEA, 2002). Altun, Turgut and Büyükkasap (2009) state that project-based learning is a learning approach that considers projects as part of infrastructure. In this model, learning is based on assignments to solve everyday problems. This activity provides broad opportunities for students to use their thinking and acting skills both individually and collaboratively. Project based learning has the following advantages that makes it stand out among other pedagogies; it engages learners, boosts cooperative learning skills, improves academic performance, develops high order thinking skills and builds positive relationships between students and teachers (Thomas, Mergendoller, and Michaleson, 2000).

The successful implementation of PBL in the classroom lies on the teacher's ability to effectively scaffold students' learning, motivate, support and guide them along the way (Kokotsaki, Menzies, and Wiggins, 2016, p.272). Thus, teacher needs to use a module in teaching. Modules are learning materials that are systematically designed based on a particular curriculum and packaged in the form of the smallest learning unit and allow to be studied independently in a certain time unit (Purwanto et al., 2007, p.9). Unfortunately, a module specifically supporting students' critical thinking skills development has not been developed yet. Based on the problems, the purpose of this study was to develop project-based learning science module that is feasible to be implemented in science learning and has potency to improve critical thinking skills of junior high school students.

\section{METHOD}

The study was research and development (R\&D). The development model used refered to the main steps of Borg \& Gall (1983, p. 775) with a few adjustments. The steps covered only research and information collecting, planning, a preliminary form of product development, expert judgment, product revision, and the final product (Wibowo, 2018, p.41). The subjects were 2 expert lecturers (content expert and media expert) and 2 science teachers of SMP N 1 Wonosari. The types of data were quantitative and qualitative. Data were collected by means of module validation sheets and critical thinking skills identification sheets. The techniques of data analysis were descriptive analysis of qualitative and quantitative to 5 grading scale. Suggestions were selected to be used as a basis for module improvements, while scores were analysed with steps as follows: (1) tabulate all data obtained from the validator for each component of the assessment, (2) calculate the average score of each component, and (3) convert the average score into a value with criteria according to Azwar (2011, p. 163). Reference of score conversion is presented in Table 1. The module is feasible to be used in science learning if each component has "very good" category. 
Table 1. Score conversion reference into value with criteria

\begin{tabular}{cc}
\hline Scores Range & Category \\
\hline $\mathrm{X}>\mathrm{Mi}+1.5 \mathrm{Sbi}$ & Excellent \\
$\mathrm{Mi}+0.5 \mathrm{Sbi}<\mathrm{X} \leq \mathrm{Mi}+1.5 \mathrm{Sbi}$ & Very Good \\
$\mathrm{Mi}-0.5 \mathrm{Sbi}<\mathrm{X} \leq \mathrm{Mi}+1.5 \mathrm{Sbi}$ & Good \\
$\mathrm{Mi}-0.5 \mathrm{Sbi}<\mathrm{X} \leq \mathrm{Mi}-1.5 \mathrm{Sbi}$ & Fair \\
$\mathrm{X}<\mathrm{Mi}-1.5 \mathrm{Sbi}$ & Poor \\
\hline
\end{tabular}

Description:

$\mathrm{X}=$ actual score

$\mathrm{M} \quad=$ ideal score average

$=(1 / 2)$ (ideal highest score + ideal lowest

score)

$\mathrm{s} \quad=$ ideal standard deviation

$=(1 / 2)(1 / 3)$ (ideal highest score - ideal

lowest score)

Ideal highest score $=\sum$ criteria item $\mathrm{x}$ highest score

Ideal lowest score $=\sum$ criteria item $\mathrm{x}$ lowest score

\section{RESULT}

\section{Feasibility of PBL science module}

Result of the preliminary studies show that students have not had good critical thinking skills. It is because they were still accustomed to listening, taking notes, and doing exercises in their learning. Many science teacher rarely applied active learning so there is a little chance for students to engage in activities that explore their critical thinking. Besides, learning materials specifically supporting students' critical thinking skills development is not yet widely available. Moreover, most of science teachers have not been able to develop it independently.

Based on preliminary study, it was determined that selected product to be developed is module. The theme of the module is "Perubahan Benda di Sekitar Kita". It is developed based on basic competencies (KD) 3.5 i.e. understanding the characteristics of substances and physical and chemical changes in substances that can be utilized in everyday life and 4.6 i.e. perform a separation of mixtures based on physical and chemical properties. In this topic, two project activities can be developed, namely observation of physical and chemical changes phenomena that happen in everyday life; and creation of simple water purification devices or distillation devices.

Components of the module refer to Surahman and Vembriarto in Prastowo (2015, p.113-114) including:

a. Learning objectives that are clearly formulated;

b. Description of learning material that is packaged into small / specific units;

c. Examples and illustrations that support clarity of learning material;

d. Quiz, assignments, and test allow students to respond and measure their level of mastery;

e. Summary of learning material;

f. Instruments that students can use to measure or evaluate the level of mastery of matter;

g. Feedback on assessment, so students know the level of mastery; and

h. Reference or enrichment that supports the intended learning material.

Module draft was validated by content experts, media experts and science teachers. Validator are expected to give advices for improvement of the module as well as giving a score to determine quality criteria of it. There are four feasibility aspects of module that are assessed, namely content, presentation, construction requirement, and technical requirement (Depdiknas, 2008, p.28). Results of module quality assessment by experts and teachers are presented in Table 2 below.

Table 2. The results of module quality assessment

\begin{tabular}{lcccc}
\hline \multirow{2}{*}{$\begin{array}{l}\text { Feasibility aspects } \\
\text { of module }\end{array}$} & \multicolumn{2}{c}{ Expert/ lecturer $(\mathbf{N}=\mathbf{2})$} & \multicolumn{2}{c}{ Teacher $(\mathbf{N}=\mathbf{2})$} \\
\cline { 2 - 5 } & Score & Category & Score & Category \\
\hline Content & 3.28 & Excellent & 3.57 & Excellent \\
Presentation & 3.56 & Excellent & 3.88 & Excellent \\
Construction Requirements & 3.00 & Very good & 3.58 & Excellent \\
Technical requirements & 3.10 & Very good & 3.20 & Very good \\
\hline
\end{tabular}

Table 3.

Besides, experts and teachers also give comments and suggestions to improve the module as follow in 
Table 3. The comments and suggestions of experts and teachers toward the module

\begin{tabular}{cl}
\hline No & \multicolumn{1}{c}{ Comments and Suggestions } \\
\hline 1. & Display pictures supporting facts to make them clearer \\
2. & The question in Essential question is not yet focused \\
3. & Need to add interactive questions \\
4. & There are some less communicative sentences \\
5. & There are several inappropriate terms used \\
6. & The layout still leaves unuseful space \\
7. & Material should be placed after the activity so that it can stimulate students' critical thinking skills \\
8. & Select appropriate color contrast in "Create a Schedule" and "Monitoring Project" section \\
9. & Activity instructions should be placed before monitoring table \\
10. & Material should be ordered from easy to difficult one \\
11. & Need a consistency in writing image sources \\
12. Need to add essay question in "Uji Kompetensi 2" \\
13. & Answer key does not need to be reversed \\
\hline
\end{tabular}

Table 2 shows the quality criteria of each feasibility aspect. Firstly, content aspect of the module is categorized as "excellent". Both experts and teachers declare that materials presented in the module have compatibility with competences. In terms of concept truth, almost all of the concepts in accordance with the applicable definitions in the field of science, do not give a lot of interpretations, and do not effect misconceptions. Furthermore, Most of the facts presented are suitable to reality, right, and do not force the will and do not conflict with the previous facts. The existence of elements and syntax of PBL, aspects of critical thinking skills and correlation between them are main identifier of this aspect. All of PBL steps have been formulated in learning activities. In addition, assignments and activities can encourage students to develop all aspects of critical thinking skills

Secondly, according to experts and teachers, presentation aspect is categorized as "excellent". It indicates that most of sequence patterns of images and text presented in the module are systematic and in accordance with the characteristics of the material. It just needs a slight improvement in presentation of chemical reaction material in order to be more easily understood. In addition, there are clear learning objectives in each learning activity and most of the material presented in accordance with the learning objectives. The module content provides an attraction to students to learn, and most of activities and assignments provide opportunities for students to interact with objects or problems. In terms of presentation, all images are presented with clear reference sources, the instructions for using modules are easy to understand, and do not cause many interpretations. The questions presented reflect aspects of critical thinking and help students to find concepts independently. Then, bibliography is also written with correct rules.

Thirdly, construction requirements aspect is rated "very good" by the experts, whereas it is rated "excellent" by the teachers. It indicates that most of languages used in the module in accordance with level of students development, simple, systematic, and easy to be understood. In addition, most of sentences in accordance with enhanced spelling and do not give rise to a double interpretation. Then, Most of information used is in accordance with the facts and science concept, clear, and increase the understanding of students. Furthermore, the term is written correctly, according to the concept, does not create a double meaning, accompanied by a detailed explanation, and given a special sign.

Lastly, different from other aspect, technical requirements is rated "very good" by both the experts and teachers. The use of the typeface, font size, spacing and number of lines per page are suitable. Nevertheless, improvements of font type in the preface section and font color in the syntax title are needed. Lay out of content is interesting, systematic and organized neatly / regularly, but in a few pages still leaves a lot of free space. In general, illustrations, graphics, images, photos are in accordance with the concept, clear, interesting, and presented in color, yet there are some illustrations that are less interactive. In addition, cover design, color, letters are good and illustrates the module contents.

A minor revision to the module based on the comments and suggestions listed in Table 3 had been done. Then, it result a final module. Because in general the quality of module is categorized as "excellent", so it can be said that the module is feasible to be used in science learning.

2. The potency of the module in developing critical thinking skills

The purpose of this module is to improve students' critical thinking skills including connecting, classifying and classifying, formulating, analyzing, comparing and making conclusions aspects (Ministry Education of Malaysia, 2002, p.5; 
Alex Fisher, 2008, p.8; Bernie Trilling and Charles Fadel, 2009, p.51). To achieve it, PBL model was chosen to arrange learning activities in the module. PBL has syntaxes including essential questions, design a plan, create a schedule, monitoring project, assessment, and evaluate (The George Lucas Educational Foundation, 2004; Abdul Majid and Chaerul Rochman, 2014, p.168). Start with essential question, design a plan for the project, and assess the outcome phase are closely related to critical thinking aspects. Correlation between PBL syntaxes and critical thinking skills aspects are described in Table 4. To ensure appearance of critical thinking skills aspects in the module, the validation of experts was applied. The results of experts validation presented in Table 5.

Table 4. The correlation between PBL syntax and critical thinking skills aspects

\begin{tabular}{ll}
\hline $\begin{array}{c}\text { The Syntax of } \\
\text { PBL }\end{array}$ & \multicolumn{1}{c}{$\begin{array}{c}\text { Aspects of critical thinking } \\
\text { skills }\end{array}$} \\
\hline $\begin{array}{l}\text { Start with } \\
\text { essential } \\
\text { question }\end{array}$ & $\begin{array}{l}\text { analyzing, connecting, } \\
\text { formulating, and comparing }\end{array}$ \\
\hline $\begin{array}{l}\text { design a plan for } \\
\text { the project }\end{array}$ & analyzing, formulating \\
\hline $\begin{array}{l}\text { assess the } \\
\text { outcome }\end{array}$ & $\begin{array}{l}\text { classifying, comparing, } \\
\text { analyzing, and making } \\
\text { conclusions }\end{array}$ \\
\hline
\end{tabular}

Table 4 illustrates that three phases of PBL i.e. start with essential question, design a plan for the project, and assess the outcome are connected with certain aspect of critical thinking skills. First, start with essential question stage is the provision of the initial question that directs the project to be carried out. Through these questions will facilitate students to improve analyzing, connecting, formulating, and comparing aspects. Next, design a plan for the project is phase of designing a project plan will be carried out. It contains selection of activities to answer essential questions by integrating various possible subjects, as well as knowing tools and materials to assist completion of the project. It certainly involves thinking activities that are not simple. Therefore, this stage facilitates students to develop analyzing, and formulating aspects. Finally, in assess the outcome stage, students are asked to do several questions related to the project has been done. It will facilitate students to grow classifying, comparing, analyzing, and making conclusions aspects.

Table 5 describes the appearance of critical thinking aspect in the module section. Every aspect is integrated through three syntaxes of PBL and "Seputar Modul" section. The experts declare that all of the components are clearly stated in the module. All in all, it can be said that the PBL module has potency in improving critical thinking skills student if it is used in science learning.

Table 5. Validation result of integrating critical thinking skills aspects into the module

\begin{tabular}{|c|c|c|}
\hline \multirow{2}{*}{ No. } & \multirow{2}{*}{ Components } & Existence/ potency \\
\hline & & Yes No \\
\hline 1. & $\begin{array}{l}\text { The module presentation generally covers all aspects of critical thinking skills } \\
\text { (connecting, classifying and classifying, formulating, analyzing, comparing } \\
\text { and making conclusions) }\end{array}$ & $\sqrt{ }$ \\
\hline 2. & $\begin{array}{l}\text { The "Seputar Modul" section presents information, descriptions, and } \\
\text { distribution of critical thinking skills aspects in the module }\end{array}$ & $\sqrt{ }$ \\
\hline 3. & $\begin{array}{l}\text { The "Start with essential question" section facilitates students to develop } \\
\text { critical thinking skills aspects: analyzing, connecting, formulating, and } \\
\text { comparing }\end{array}$ & $\sqrt{ }$ \\
\hline 4. & $\begin{array}{l}\text { The "Design a plan for the project" section facilitates students to develop } \\
\text { critical thinking skills aspects: analyzing, formulating }\end{array}$ & $\sqrt{ }$ \\
\hline 5. & $\begin{array}{l}\text { The "Assess the outcome" section facilitates students to develop critical } \\
\text { thinking skills aspects: classifying, comparing, analyzing, and making } \\
\text { conclusions }\end{array}$ & $\sqrt{ }$ \\
\hline
\end{tabular}




\section{CONCLUSIONS}

Based on the results and discussion above, it can be concluded that PBL science module has been developed and rated as "excellent" category. That is why it is feasible to be implemented in science learning and has potency to improve critical thinking skills of junior high school students.

\section{REFERENCES}

Abdul Majid dan Chaerul Rochman. (2014). Pendekatan Ilmiah dalam Implementasi Kurikulum 2013. Bandung: PT Remaja Rosdakarya

Andi Prastowo. (2015). Panduan Kreatif Membuat Bahan Ajar Inovatif. Yogyakarta: Diva Press

Bernie Trilling \& Charles Fadel. (2009). 21 st Century Skills Learning for Life in Our Times. San Fransisco: Wiley

Borg, W. R., \& Gall, M. D. (1983). Educational Research: An Introduction (4 $4^{\text {th }}$ ed.). New York \& London: Longman Inc.

Budi Utami, et al. (2017). Critical thinking skills profile of high school students in learning chemistry. Int. J. Sci. Appl. Sci.: Conf. Ser., 1 (2), 124-130

Chiappetta, E. L \& Koballa, T. R. Jr. (2010). Science Instruction in The Middle and Secondary School (7th ed). New york: Pearson Education, Inc.

Depdiknas. (2008). Panduan Pengembangan Bahan Ajar. Jakarta: Depdiknas

Duron, Robert, et al. (2006). Critical Thinking Framework For Any Discipline. International Journal of Teaching and Learning in Higher Education, 17 (2), 160-166

Fisher, Alex. (2008). Berpikir Kritis: Sebuah Pengantar. Jakarta: Erlangga

George Lucas Educational Foundation [GLEF]. (2004). Project Based Learning Research. August 20, 2004, retrieve from http://www.glef.org/PBL/research.html.

Halpern, D. F. (2014). Thought and Knowledge. Fifth edition. NY: Psychology Press.

Kemdikbud. (2016). Peringkat dan capaian PISA Indonesia mengalami peningkatan. Retrieved from https://www.kemdikbud.go.id/main/blog /2016/12/peringkat-dan-capaian-pisaindonesia-mengalami-peningkatan
Kokotsaki, D., Menzies, V., \& Wiggins, A. (2016). Project-based learning: A review of the literature. Improving Schools, 19 (3), 267-277

Ministry of Education Malaysia. (2002). Integrated Curriculum for Secondary Schools. Malaysia: Curiculum Development Center

National Education Association. (2002). Preparing 21st Century Students for a Global Society : An Educator's Guide to the "Four Cs". Retrieved From https://www.nea.org/assets/docs/A-Guide-toFour-Cs.pdf.

Partnership for 21st Century Skills. (2009). Learning for the 21st century skills. Retrieved from www.21stcenturyskills.org.

Purwanto dkk. (2007). Pengembangan Modul. Jakarta: Pusat Teknologi Informasi dan Komunikasi Pendidikan (PUSTEKKOM) Depdiknas.

Rotherham, A. J., \& Willingham, D. (2009). 21st Century Skills: the challenges ahead. Educational Leadership, 67 (1) , 16 - 21.

Thomas, H, W. Mergendoller, J. R. Michaleson, A., (2000). Projects based learning: A handbook for middle and high school teachers. Navato, CA: the Buck institute for Education

Widodo Setiyo Wibowo. (April, 2014). Implementasi Model PBL dalam Pembelajaran Sains untuk Membangun 4Cs Skills Peserta Didik sebagai Bekal dalam Menghadapi Tantangan Abad 21. Paper presented in Seminar Nasional IPA V, Universitas Negeri Semarang.

Widodo Setiyo Wibowo. (2018). Surrogate Experiential Learning-based science Subject Specific Pedagogy (SSP) to build disaster preparedness of junior high school students on volcanic eruption. Journal of Science Education Research, 2 (1), 39-46

Yalcin Sema Altun, Turgut Umit, Buyukkasap Erdogan, (2009). The Effect of Project Based Learning on Science Undergraduate Learning of Electricity, Attitude towards Physics and Scientific Process Skills. International Online Journal of Educational Sciences, 1 (1), 81-10.

Zulfaneti et al. (2018). Enhancing students' critical thinking skills through critical thinking assessment in calculus course. J. Phys.: Conf. Ser. 948012031. 